\title{
LWÓW WIEKU XX-XXI. DORASTANIE I KONFLIKT POKOLEŃ W DOBIE PRZEMIAN SPOŁECZNYCH I REWOLUCJI (NA PODSTAWIE DOMU Z WITRAŻEM ŻANNY SŁONIOWSKIEJ)
}

\author{
Katarzyna Jakubowska-Krawczyk \\ Uniwersytet Warszawski, Warszawa, Polska \\ ORCID: 0000-0002-6281-7011
}

\begin{abstract}
Streszczenie. W artykule przeanalizowano powieść Żanny Słoniowskiej Dom z witrażem pod kątem relacji pomiędzy zamieszkującymi go czterema pokoleniami kobiet. Skoncentrowano się na procesie kształtowania się tożsamości najmłodszej bohaterki. Przeanalizowano wpływ, jaki wywarły na nią doświadczenia terroru i wojny, które spotkały jej prababkę i babkę, a także zaangażowanie polityczne oraz śmierć matki. Poszukiwano także odpowiedzi na pytanie o miejsce, jakie w procesie kształtowania się jej tożsamości zajmuje Lwów i jego pejzaż semantyczny.
\end{abstract}

Słowa kluczowe: Żanna Słoniowska, Dom z witrażem, Lwów, tożsamość, doświadczenie historyczne, konflikt pokoleń.

Lwów to miasto szczególne, od lat inspirujące twórców swoim duchem i niepowtarzalnością. Mieszają się w nim elementy różnych kultur, obrzędy i zwyczaje wielu wyznań. Wielokulturowość niosła ze sobą jednak nie tylko piękne przykłady inspirującego współistnienia, ale i sytuacje trudne, a czasem bolesne. Wszystkie te elementy tworzą jednak fascynującą mozaikę, pozwalającą na odkrywanie wciąż nowych przestrzeni miasta, tak w znaczeniu dosłownym, jak i przenośnym ${ }^{1}$. Nie powinno więc dziwić, że Żanna Słoniowska umieściła właśnie we Lwowie akcję swojej powieści. Jak stwierdził jej ukraiński tłumacz, Andrij Porytko: „Мені вона була цікава передовсім як львівський текст. Крім Високого замку Лема складно знайти більш львівську книжку"2.

Żanna Słoniowska urodziła się w 1978 roku we Lwowie w rodzinie z polskimi korzeniami. W wieku szesnastu lat zadebiutowała jako dzien-

\footnotetext{
1 O literaturze poświęconej miastu Lwów pisała m.in. Katarzyna Kotyńska (zob. K. Kotyńska, Lwów. O odczytywaniu miasta na nowo, Kraków 2015).

2 Жанна Слоньовська: «Описала Львів як власне тіло, де вулииі - капіляри», https:// starylev.com.ua/news/zhanna-slonovska-opysala-lviv-yak-vlasne-tilo-de-vulyci-kapilyary, [dostęp: 10.01.2019].
} 
nikarka, później zajęła się również pracą przekładową i pisarską. Od 2002 roku mieszka w Polsce. Swoją pierwszą książkę poświęciła lwowskim fotografiom okresu przedwojennego. W 2015 roku światło dzienne ujrzała jej debiutancka powieść Dom z wirażem, która wygrała konkurs Wydawnictwa „Znak”. W 2016 roku Słoniowska otrzymała za nią Nagrodę Conrada oraz nominację do Nagrody Literackiej „Nike”. Na pytanie, dlaczego Lwów stał się najważniejszym tematem jej twórczości, pisarka odpowiada, że to emigracja „дає можливість оцінити певні речі, що раніше вважалися природними. Наприклад, Краків дав мені силу описати пережите у 80-х, в часи мого дитинства. Відомі діячі, описані в книзі, - Крушельницька, Чорновіл та інші - це свого роду меми-символи Львова. Вони почали зі мною спілкуватися лише коли я виїхала зі Львова"з.

Dom $z$ witrażem to nie tylko narracja o Lwowie i odzyskiwaniu przez Ukrainę wolności, ale przede wszystkim opowieść o skomplikowanych losach jej mieszkańców, borykaniu się z historią, która wkracza w życie jednostki, konfrontacji bohaterów z przeszłością własną i własnej rodziny. Fabuła powieści zaczyna się pod koniec lat 80 ., w czasie trwania protestów przeciwko panującemu reżimowi, ostatnie zaś jej strony poświęcone są rewolucji godności. Osią utworu jest nałożenie się na siebie procesów przemian społecznych, specyfiki Lwowa i identyfikacji narodowej rodziny bohaterek.

Żanna Słoniowska w swojej powieści dotyka problemu dyskursu pokoleniowego wobec tradycji przodków, w tym również polskości. Jak zauważyli autorzy pracy Kategoria pokolenia we wspótczesnych badaniach społeczno-kulturowych, Agnieszka Matusiak i Mateusz Świetlicki, kolejne pokolenia są odpowiedzialne za transmisję „dziedzictwa narodowego i pamięci kolektywnej, jak też kontestowania starego ładu i kanonu kultury, dzięki czemu możliwa jest zmiana, a w konsekwencji również rozwój. Stąd - jeśli wziąć pod uwagę traumatyczny charakter transferu memorialnego o przeszłości (zwłaszcza tej najbliższej, czasach realnego socjalizmu) oraz samego przełomu ustrojowego w społeczeństwach posttotalitarnych i ich kulturach - kategoria pokolenia (a także symbiotycznie powiązane z nią świadomość i dyspersja pokoleniowa) okazuje się optymalnym instrumentem badawczym do prześledzenia, zrozumienia oraz opisania charakteru i mechanizmów zmian paradygmatów społeczno-kulturowych, mających prowadzić do przewartościowania totalitarnej przeszłości krajów postkomunistycznych"4. Tę właśnie drogę wybrała autorka Domu z witrażem. W centrum powieściowych wydarzeń stoi główna

Ibidem.

4 A. Matusiak, M. Świetlicki, Kategoria pokolenia we wspótczesnych badaniach społeczno-kulturowych, [w:] Posttotalitarny syndrom pokoleniowy w literaturach słowiańskich Europy Środkowej, Wschodniej i Poludniowo-Wschodniej końca XX-początku XXI wieku w świetle studiów postkolonialnych, red. nauk. A. Matusiak, Poznań - Wrocław 2016, s. 18. 
bohaterka, imienia której czytelnik nie poznaje, jej matka Marianna, babka nazywana Abą oraz prababka Stanisława. Poszukując odpowiedzi na pytanie o bezimienność tej pierwszej, Anna Szulc stwierdza:

Kim jednak jest narratorka? Dlaczego pisarka nie dała jej imienia? Na pewnym poziomie jest po prostu młodą dziewczyną, uwikłaną $\mathrm{w}$ dziwny romans $\mathrm{z}$ dawnym kochankiem matki. Na innym, kimś, kto na gruzowisku historii, w plątaninie przebrzmiałych i nowych idei, szuka odpowiedzi, jak określić i wyrazić siebie ${ }^{5}$.

Każda z bohaterek powieści niesie przez życie swoje przeżycie pokoleniowe - wojny, terroru radzieckiego, walki Ukrainy o niepodległość czy wreszcie świeżo odzyskanej wolności i kolejnych prób budowania państwa. Wydarzenia historyczne za każdym razem wchodzą w dialog z ich własnym poczuciem tożsamości, narodowościowym, kulturowym i społecznym określaniem siebie samych. Przewodnikiem po wędrówce przez historię mieszkającej we Lwowie rodziny jest młoda bohaterka, która jako dziewczynka przeżyła śmierć matki zabitej na jednym z wieców Wiaczesława Czornowoła. Ta tragiczna chwila staje się przełomowa, od niej zaczyna się coraz bardziej świadoma wędrówka bohaterki przez otaczający świat, wnikanie w historię rodziny, poszukiwanie tożsamości i odkrywanie kolejnych warstw kulturowo-narodowościowych, które ją ukształtowały. Przez pryzmat życiowych doświadczeń kobiet zamieszkujących tytułowy dom z wirażem czytelnik zostaje wprowadzony w niezwykle skomplikowane losy mieszkańców tych ziem oraz ich próby zmagania się z wydarzeniami historii XX i XXI wieku. Jak zauważył Bogusław Bakuła, cechą charakterystyczną literatur krajów Europy Środkowo-Wschodniej jest ukazywanie oceny wydarzeń historycznych poprzez starcie poglądów osób młodych i dojrzałych. Daje to pisarzom możliwość zestawienia tożsamości indywidualnej ze zbiorową oraz pokazanie ich wzajemnego przenikania się. Wedle literaturoznawcy konflikt ów jest „pretekstem do literackiego szlifowania charakterów, do pieczołowitego budowania historycznego ducha narodowego i konstruowania określonej perspektywy dla egzystencji zbiorowej" ${ }^{6}$. Bohaterkami Domu z witrażem są cztery kobiety o niesłychanie silnych charakterach, które kochają się, wchodząc zarazem ze sobą w ostre konflikty trwające często aż do śmierci.

\footnotetext{
5 A. Szulc, Przypadki chodza po Lwowie, czyli „Dom z witrażem” Stoniowskiej [recenzja], https://www.newsweek.pl/kultura/dom-z-witrazem-zanny-sloniowskiej-recenzja-ksiazki-o-lwowie/tcmdh5j, [dostęp: 4.07.2019].

6 B. Bakuła, Pamięć: ciagłość i zerwanie. Ojcowie i dzieci wobec historii we wspótczesnej powieści i filmie z Europy środkowo-wschodniej (na wybranych przyktadach), [w:] Posttotalitarny syndrom pokoleniowy w literaturach słowiańskich Europy Środkowej, Wschodniej i Poludniowo-Wschodniej końca XX-początku XXI wieku w świetle studiów postkolonialnych, red. nauk. A. Matusiak, Poznań - Wrocław 2016, s. 200.
} 
Losy wszystkich bohaterek naznaczają przeżycia i życiowe wybory nestorki rodu, prababki Stanisławy. Ta silna osoba spędziła swą młodość w Leningradzie, marząc o karierze śpiewaczki operowej. Jako jedna z pierwszych kobiet została przyjęta do chóralnej Kapeli Akademickiej, gdzie szybko doceniono jej talent i powierzono zaszczytną funkcję zastępcy dyrygenta chóru. Tam też poznała swojego męża i spędziła szczęśliwe lata. Wspominała je jako wypełnione dostatnim życiem, eleganckimi balami i kulturalnymi spotkaniami. Sielanka ta jednak nie trwała długo, gdyż w 1937 roku jej męża zaaresztowano w ramach ,akcji polskiej” i nigdy go już nie zobaczyła. Po wojennej tułaczce znalazła się wraz z córką we Lwowie.

Dla Stanisławy lwowska, powojenna rzeczywistość miała kolory, a przede wszystkim jej ulubiony kolor - zielony. Nie skończyła jeszcze trzydziestu pięciu lat, była wdową z dzieckiem, paliła skręty z tanim tytoniem, lubiła swoje wychudzone do granic ciało w kolorze opalu i duże matowe oczy w odcieniu jadeitu, pracowała jako sekretarka w nowo utworzonej radzie obwodowej, urządzonej naprędce w byłym Pałacu Wojewódzkim. Na wiosnę potrafiła popłakać się ze wzruszenia, głaszcząc krzaki i drzewa $[\ldots]^{7}$.

Z czasem jednak te kolory przyblakły i codzienna walka o przetrwanie przerodziła się w oschłość i dystans wobec świata. Bohaterka całe swoje życie spędziła w cieniu doznanej traumy. Jak twierdzi Ankersmit, wzniosłość i trauma są matrycami doświadczenia historycznego. „Trauma [...] jest psychologicznym odpowiednikiem filozoficznej wzniosłości. Obie te kategorie są odniesione do pamięci i wzniosłości w jej zbiorowym i jednostkowym rozumieniu"s. W przypadku prababki Stanisławy trauma konstytuowała jej tożsamość, a jednocześnie nadała jej głębszego sensu. Poświęcenia, które zmuszona była ponieść, budowały w niej przekonanie o szczególnym znaczeniu i uwzniośleniu jej egzystencji, skutkiem czego domagała się (w swoim mniemaniu) należnego jej podporządkowania i wdzięczności od innych, przede wszystkim zaś swojej córki. Nastawienie takie odcisnęło swe mocne piętno na świadomości, ale też historii kolejnych pokoleń.

Jej córka, nazywana przez główną bohaterkę powieści Abą, mieszkała w Leningradzie i jako siedmioletnia dziewczynka straciła ojca. Widziała, jak zabiera go NKWD. Jako sześćdziesięcioletnia kobieta przeżyła we Lwowie śmierć córki, również zabitej przez przedstawicieli aparatu władzy. Tak, jakby przeznaczenie dosięgało ją niezależnie od miejsca zamieszkania. Całe jej życie wypełniało poczucie niesprawiedliwości i nienawiść wobec tych, którzy wtargnęli w jej życie i je niszczyli:

Ż. Słoniowska, Dom z witrażem, Kraków 2015, s. 146.

8 Cyt. za: D. Wolska, Odzyskać doświadczenie. Sporny temat humanistyki współczesnej, Kraków 2012, s. 77. 
Pomiędzy jednym a drugim wydarzeniem nie przestała ich nienawidzić, a także mniej lub bardziej otwarcie to wyrażać. Gdy w czterdziestym czwartym trafiła do Lwowa, postanowiła zostać jednoosobową organizacją ruchu oporu - sama robiła i roznosiła ludziom do skrzynek pocztowych ulotki, w których napisane było, że Stalin jest zbrodniarzem? .

Szybko jednak zrozumiała jałowość takich działań. Aba doświadczyła nie tylko traumy wojny, ale i oschłości, czasem graniczącej wręcz z odrzuceniem ze strony matki. Bohaterka w powieści cierpi na reumatoidalne zapalenie stawów. Jak wyznała w jednym z wywiadów Słoniowska:

Jej choroba symbolizuje unieruchomienie. Aba nigdy się nie uwolniła od matki, ponieważ matka do końca wypominała jej poświęcenie z czasów wojny: głód, oddawanie ostatniej porcji chleba. Myślę jednak, że mimo tego okrutnego szantażu dla Aby najgorsza, traumatyczna wręcz była świadomość, że matka jej nie kocha, że nie doznaje z jej strony czułości i bliskości. Ona cały czas żywi się okruszkami tej miłości, którą jej matka daje kochankom ${ }^{10}$.

Aba żyła w ciągłym cieniu matki i podporządkowywała jej woli swoje życie w nawet najbardziej osobistych decyzjach, jak chociażby wybór męża czy zawodu. Posługując się terminologią Hansa Joasa, moglibyśmy powiedzieć, że życie bohaterki było zawieszone pomiędzy więziami restrykcyjno-zobowiązującymi a atrakcyjno-motywującymi ${ }^{11}$. Jej tożsamość konstytuowały oba typy, przewagę zyskiwał jednak ten pierwszy. ,[...] Aba była ofiarą, ma nawet psychologiczne cechy ofiary. Ale mogła być ofiarą wyłącznie sfrustrowaną i zgorzkniałą, a ona potrafiła zostawić sobie obszar twórczości, miłości i dobra, rozwijać się (w odróżnieniu od swojej matki, która zatruwała wszystkich dookoła). Kiedyś była wziętą lekarką, ale już jest na emeryturze. Nie zostało jej nic oprócz wspomnień i tego malowania od czasu do czasu. To jedyny obszar jej wolności"12 - dodaje Słoniowska. Poczucie obowiązku, a po części też chyba i winy, że matka przez nią cierpiała, kazało jej jednak pozostawać za wszelką cenę wobec niej lojalną, spychając na drugi plan swoje osobiste potrzeby, ambicje i marzenia. Rodziło to wewnętrzne pęknięcia i rozgoryczenie, które nie mogło się nie udzielić jej córce. Ta jednak za wszelką cenę próbowała żyć inaczej. Marianna, matka głównej bohaterki, również dość wcześnie osierocona i wychowująca się $\mathrm{w}$ domu bez mężczyzn ${ }^{13}$, postanowiła przerwać panującą

$9 \quad$ Ż. Słoniowska, op. cit., s. 24.

10 Żanna Stoniowska: Dom z witrażem z Nagroda Conrada (wywiad), https://www.miastokobiet.pl/zanna-sloniowska-dom-z-witrazem-z-nagroda-conrada-wywiad/, [dostęp: 10.01.2019].

11 Por. H. Joas, Powstawanie wartości, tłum. M. Kaczmarczyk, Warszawa 2009.

12 Żanna Stoniowska: Dom z witrażem z Nagroda Conrada (wywiad).

13 W jednym z wywiadów Żanna Słoniowska stwierdza: „Читачi нерідко закидають мені, що чоловіки у романі міфічні, а жінки реальні. Я сама шукаю відповідь на запитання, чому у моїй книзі виник світ без чоловіків. Можливо тому, що мене завжди інтригував 
w nim dyktaturę Stanisławy, a swoich życiowych wyborów nie uzależniać od jej akceptacji. Efektem był ostry, wieloletni konflikt między bliskimi sobie kobietami. Wbrew woli babki skończyła jednak konserwatorium i pracowała jako podziwiana śpiewaczka w operze. Była silna i niezależna, jak ona. Pomimo nalegań rodziny nie przerwała nieplanowanej ciąży, nie poinformowała też o niej ojca swojego dziecka. Podobnie decyzji o swym zaangażowaniu społeczno-politycznym, które miało mieć dla niej skutek tragiczny, nie konsultowała z matką ani babką. Stworzyła własny system wartości, jakby na siłę próbując odciąc się od rodzinnych schematów. Na pierwszym miejscu stawiała sztukę, a potem walkę z systemem, nieco na uboczu zostawiając potrzeby swojego dziecka. Jak podkreślali Charles Taylor czy H. Joas, wyobrażenia o tym, co jest słuszne i wartościowe, tworzy sposób rozumienia siebie ${ }^{14}$ i swojej tożsamości. Nie ma jednak innego sposobu, aby przekonać się o słuszności głoszonych poglądów, niż skonfrontowanie ich ze światem, podejmowanie zgodnych z nimi działań. Tak też, nie zważając na konsekwencje, czyniła Marianna. Cenę za tę bezkompromisowość miała jednak zapłacić przede wszystkim jej córka.

Główną bohaterkę czytelnik poznaje jako dziewczynkę uczącą się poruszać po panujących w rodzinie meandrach relacji międzypokoleniowych. Bohaterka bardzo podziwia swoją matkę i pragnie być jak najbliżej niej. Ojca nigdy nie poznała, całą więc swoją dziecięcą miłością i zaufaniem obdarzyła kobietę, która dała jej życie. Szybko, zbyt szybko, zostaje jednak jej pozbawiona. Matka ginie na jednym z wieców niepodległościowych od kuli przeznaczonej dla Wiaczesława Czornowoła. Jej pogrzeb przeradza się w wielką manifestację polityczną, ale czy może to być pocieszeniem dla pozbawionej matki dziewczynki? Postać matki i wspomnienia jej dotyczące dominują życie najmłodszej protagonistki. Bohaterka stara się żyć tak, jak ona by sobie tego życzyła, patrzeć na świat jej oczami, stara się

oddać uniesieniu i ekstazie, bo patrzyła na tę nową przyszłość tak, jak by to robiła Mama, której wszystkie nadzieje spełniały się na naszych oczach. „Karnawał” trwał równocześnie za oknem i na ekranie telewizora: ostatnie sowieckie czołgi opuszczały teren Afganistanu. Padał mur berliński - Mścisław Rostropowicz przygrywał temu na wiolonczeli. Polacy uczestniczyli w pierwszych wolnych wyborach. Rumuni zabili dyktatora Ceauşescu. Litwa ogłosiła suwerenność. Rosyjskie miasta zaczęły pozbywać się swoich sowieckich nazw ${ }^{15}$.

\footnotetext{
факт ненависті радянської жінки до чоловіків. Я дискутувала про це з львів'янками, які застали повоєнний Львів: звідки взялося це агресивне ставлення до чоловіка? Мабуть, так склалось тому, що чоловіки йшли на війну, зникали у невідомому напрямку і залишали жінок напризволяще. Жінки відчували себе зрадженими.” (Жанна Слоньовська: «Описала Львів як власне тіло, де вулиці - капіляри», https://starylev.com.ua/news/zhannaslonovska-opysala-lviv-yak-vlasne-tilo-de-vulyci-kapilyary, [10.01.2019].)

14 Por. D. Wolska, op. cit., s. 239.

15 Ż. Słoniowska, op. cit., s. 26.
} 
Aby zachować dłużej wspomnienia o mamie, dziewczynka nosiła jej ubrania, dbała o pamiątki po niej, walczyła o jej pamięć. Z czasem zaangażowanie to jednak słabło, a jej poglądy poddawane były krytycznej ocenie. Wobec wyzwań, które niosło dojrzewanie w czasie ukraińskiego kryzysu lat 90. pamięć o matce schodziła na dalszy plan. Przynajmniej pozornie, bo związanie się jej po latach $\mathrm{z}$ byłym parterem matki było w pewnym sensie dla obojga próbą przywrócenia pamięci o minionych latach.

Mając świadomość niezwykle skomplikowanych powiązań rodzinnych, główna bohaterka próbuje odzyskać doświadczenia bliskich sobie kobiet, aby móc na nowo ułożyć mozaikę swojej tożsamości. Można by tutaj sparafrazować słowa Chantal Delsol o tym, że duch, w naszym przypadku chyba duch toksycznych relacji, ,zostanie naprawdę poskromiony i pokonany dopiero wtedy, gdy [bohaterka] [...] uzna wagę doświadczenia jako koniecznego korelatu wszelkiego eksperymentu. Te dwie postawy dotyczą stosunku do rzeczywistości. Doświadczenie jest przyjmowaniem rzeczywistości, eksperyment jest wolą jej posiadania" ${ }^{16}$. Jak się wydaje, tą właśnie drogą podąża dojrzewająca córka Marianny, nie próbuje, jak jej prababka, podporządkować sobie otaczającego świata, lecz poznać go, aby starać się przyjąć go takim, jaki on jest.

Pomimo licznych napięć wszystkie cztery powieściowe pokolenia kobiet są ze sobą nierozerwalnie związane. Pisarka podsumowała to stwierdzeniem głównej bohaterki:

Moja prababka była niespełnioną śpiewaczką operową, moja babcia niespełnioną malarką, moja matka była spełnioną śpiewaczką operową, ja będę spełnioną malarką, moja córka będzie niespełnioną śpiewaczką operową albo spełnioną malarką, jej córka będzie, zależnie od tego, co wybierze moja córka, albo spełnioną śpiewaczką operową, albo spełnioną malarką, niespełnienie skrzyżowane z niespełnieniem daje spełnienie, jak w matematyce. Jesteśmy jak matrioszki, jedna siedzi w brzuchu drugiej, nie do końca wiadomo która w której, wiadomo tylko, która żyje, a która już nie, jesteśmy jak matrioszki przeszyte jednym strzałem na wylot, a ja wcześniej myślałam, że Prababki nie ma w tym łańcuchu. Była niespełnioną śpiewaczką operową, więc moja babcia jest niespełnioną malarką, a moja matka, mimo iż była primadonną, umarła ${ }^{17}$.

Wszystkie cztery kobiety kochają się i nienawidzą, nie mogą bez siebie żyć, ale zachowują chłód. Każda z nich przeżyła swój koniec świata. Trzy starsze z pewnością są najważniejszym punktem odniesienia dla najmłodszej, dla której śmierć matki staje się symbolicznym momentem inicjacji.

Opisom procesu dojrzewania towarzyszą liczne pytania o to, kim jest główna bohaterka. Żanna Słoniowska ukazuje tożsamość swojej najmłod-

16 Ch. Delsol, Esej o człowieku późnej nowoczesności, Kraków 2003, s. 39.

17 Ż. Słoniowska, op. cit., s. 155. 
szej bohaterki jako proces otwarty, krytycznie przyglądający się rzeczywistości, podlegający przemianom, poszukujący wzorów i wartości ${ }^{18}$. Ważnym elementem jej tożsamościowych poszukiwań są próby zrozumienia historii swojej rodziny i odkrywanie tajemnic najbliższych jej kobiet. Jerzy Nikitorowicz podkreśla, jak ogromne znaczenie ma tożsamość wyniesiona $\mathrm{z}$ domu rodzinnego, w którym jego tradycja spotyka się z teraźniejszością oraz tym, co dopiero ma nastąpić. To ona bowiem uczy identyfikacji z grupą i budowania trwałych więzi ${ }^{19}$. Z powieści Słoniowskiej wyłania się o wiele bardziej skomplikowany obraz sytuacji. Kobiety o silnych charakterach swoją tożsamość w pewnym stopniu budują w opozycji do działań czy poglądów swoich przodków. To bogactwo postaw pozwoliło autorce zwrócić uwagę na całą mozaikę problemów tożsamościowych obecnych na Ukrainie Zachodniej, gdzie mieszkańcy wśród swoich przodków mają przedstawicieli wielu narodowości, różniących się w ocenach teraźniejszości, postawach wobec historii, itp. Główna bohaterka staje się niejako przewodnikiem czytelnika po niektórych z tych problemów. Jej poszukiwania własnej tożsamości wydobywają na światło dzienne trudne pytania o relacje między narodami zamieszkującymi te ziemie, o ich postawy etyczne i moralne, ale także o wyobrażenia, jakie mają co do przyszłości.

Pierwszą osobą, z której spuścizną musi się zmierzyć dojrzewająca dziewczyna, jest prababka Stanisława, która po rosyjsku zapewniała rodzinę o swojej polskości. Popadała przy tym w tak smutny nastrój, że tej zdawało się, „że polskość jest czymś w rodzaju nieuleczalnej choroby, na którą [...] nie wynaleziono lekarstwa"20. Nieuleczalna była nostalgia prababki. Zapytana o nią, opowiadała o tęsknocie za ojczyzną. „Nie wiem, czy myślała o Leningradzie-Petersburgu, w którym się urodziła i mieszkała przed wojną, czy o Polsce, o której zawsze marzyła i która ze Lwowa się wyniosła"21 - konstatuje narratorka. W powieści mamy bowiem do czynienia $\mathrm{z}$ dwoma kontekstami nostalgii. $Z$ jednej strony jest ona tęsknotą za domem, z drugiej - za przeszłością, za tym, co zostało utracone i już nie wróci, a więc za życiem w Leningradzie, miłością, młodością, wystawnymi balami, itd. Dodatkowo w pierwszym przypadku mamy do czynienia z nostalgią podwójną, spowodowaną utratą domu (ten prawdziwy był w Leningradzie) i ojczyzny (ta była z kolei we Lwowie). Jak pisała Barbara Czapik-Lityńska,

[p]onowoczesność łączy pojęcie nostalgii z cierpieniem i bólem, wynikającym ze straty, z niemożności powrotu do utraconych przestrzeni i minionego czasu.

18 Por. J. Nikitorowicz, Model ksztaltowania się tożsamości kulturowej w warunkach wielokulturowości, „Psychologia Wychowawcza” 2015, nr 7, s. 127-130.

19 Por. Ibidem, s. 127-131.

20 Ż. Słoniowska, op. cit., s. 31.

21 Ibidem, s. 43. 
Kiedy ocalający powrót już-nie jest możliwy, pozostaje pustka albo nostalgiczna tęsknota. Jeśli nie jest ocalająca, to bywa empatyczna bądź wzniosła, bądź traumatyczna - według miary wyobraźni i pamięci podmiotu ${ }^{22}$.

Można odnieść wrażenie, że właśnie ten ból zaważył na całym życiu prababki, stał się jej nieodzownym towarzyszem, kształtował ją oraz jej sposób postrzegania świata. Jednocześnie była to tęsknota za światem wyimaginowanym, który już nie istnieje, a może nigdy nie istniał, bowiem wyobrażenia bohaterki o ojczyźnie nie opierają się na jej realnym obrazie, takim, jak ona wygląda tu i teraz. Ojczyzna została niejako zamknięta we wspomnieniach i pamiątkach historycznych i religijnych, obrazie Tadeusza Kościuszki czy polskim modlitewniku. Przemysław Czapliński zwraca uwagę na fakt, że nostalgia wiąże się z kontestowaniem teraźniejszości, dystansowaniem się od niej i z odnoszenia się z nieufnością do wszelkiego postępu ${ }^{23}$. W taki właśnie sposób Słoniowska skonstruowała swoją bohaterkę. Stanisława wprawdzie pocieszała się, że gdyby jej losy potoczyły się inaczej, nie byłoby dwóch najbliższych jej kobiet, jednak tęsknota przeplatała się w jej życiu z rozczarowaniem, smutkiem, poczuciem braku zadowalającego wpływu na jego kształt. Prababka przede wszystkim osadzona jest w przeszłości i do wypełnienia przeszłością przyszłości zmierza. Im więcej rozczarowań i bólu przynosi teraźniejszość, tym silniej kocha to, co minęło.

Kolejną osobą, z poglądami której przychodzi się młodej bohaterce skonfrontować, jest babka nazywana Abą. Zdecydowanie mniej miejsca poświęca ona sprawom narodowym, a więcej zajmowaniu się praktyczną stroną codziennej egzystencji. Nie pozostaje jednak im obojętna. Dla Aby polskość jest jej konkretnym doświadczeniem realności świata, który przeminął. Przypomnijmy za Dorotą Wolską, że „w koncepcji Oakshotta organomem doświadczenia jest poznanie"24, a przecież ona ten polski świat poznała. Nosi go w sobie tak jak i ból, który się z nim łączy. To niejako z jego powodu w młodym wieku straciła ojca, a gdy już wreszcie po dramatycznych przeżyciach wojennych znalazła się w Polsce, Lwów polski być przestał. „,- Polska się z niego wycofała. Dokąd? Gdzieś daleko, za granicę. Dlaczego? Nie wiadomo. Aba została, ponieważ jej ze sobą nie wzięła"25. Częścią Polski była także jej wielka miłość - człowiek zwany w rodzinie Szopenem, który „był pianistą i miał wydatny profil. Później wycofał się na Zachód, tak jak

\footnotetext{
22 B. Czapik-Lityńska, Topografia nostalgii jako topografia tożsamości (na podstawie twórczości Dubravki Ugrešić i Pavao Pavličicia), „Porównania” 2013, nr 12, s. 106.

23 P. Czapliński, Wznioste tęsknoty. Nostalgie w prozie lat dziewięćdziesiatych, Warszawa 2001, s. 5.

24 D. Wolska, op. cit., s. 34.

25 Ż. Słoniowska, op. cit., s. 32.
} 
jego ruchoma ojczyzna"26. Na życzenie matki Aba wyszła jednak za mąż za żołnierza armii radzieckiej. Polskość już na zawsze kojarzyć się jej będzie jednak z kulturą i sztuką, a w księgarni będzie kupowała polskie czasopisma. Bohaterka nosiła w sobie obraz Lwowa wielonarodowego. Gdy jej córka Marianna pewnego dnia oznajmiła, że teraz zaczyna mówić wyłącznie po ukraińsku,

Aba zareagowała na to opowieścią o polskim Lwowie i jego licznych mniejszościach narodowych, które żyły ze sobą w zgodzie. O walkach o Lwów w 1918. O zdewastowanym Cmentarzu Orląt. Mówiła o szpitalu, w którym przepracowała trzydzieści lat, gdzie każdy członek personelu mówił w swoim własnym języku, a były to rosyjski, ukraiński i polski, i nikomu nie przychodziło do głowy, aby z pobudek ideologicznych go zmieniać. Wspomniała też o polskich kołysankach i rosyjskim elementarzu, przywołała poetów rosyjskiego srebrnego wieku, których obydwie kochały ${ }^{27}$.

Dla Aby niesłychanie ważna jest pamięć kulturowa, zarówno ta funkcjonalna, jak i magazynująca, angażuje ją zarówno działanie, jak i archiwizowanie. Bezpiecznie czuje się w sytuacji, w której wielogłosowość jest stanem naturalnym i nikt nie jest zmuszany do jasnego określenia swojej tożsamości.

Inaczej zachowuje się Marianna, ona jest kobietą czynu, wymagającą od siebie i innych działań zdecydowanych. Od czasu, gdy określiła swą ukraińskość, niechętnie tolerowała kompromisy. Uważała, że czasy, w których żyje, wymagają poświęceń i walki o wolną Ukrainę, a jednocześnie rewizji historii. Czyniła to w pewnym sensie kosztem najbliższych, a szczególnie - czasu poświęcanego córce. Niejako w testamencie zostawiła jej pytania o ukraiński patriotyzm, któremu poświęciła ostatnie lata swojego życia i za który zapłaciła najwyższą cenę.

W osobie głównej bohaterki Słoniowska stawia pytania o sposoby współistnienia we Lwowie dziedzictwa trzech narodów. Dziewczynka musi zmierzyć się z polskością prababki, ukraińskim testamentem matki i elementami kultury rosyjskiej, które były obecne w domu chociażby przez język, którym się posługiwano (a także osobą ojca, którego nigdy nie poznała). Jednym z pierwszych jej doświadczeń potrzeby narodowej identyfikacji był incydent w szkole plastycznej, w której dzieci otoczywszy ją, wykrzykiwały dla zabawy „precz Moskale”. Nigdy wcześniej tak o sobie nie myślała. Wychowana w radzieckiej szkole, nie uważała też, że ma to znaczenie. Konfrontacje z postawą przodków kazały jej szukać innego wyjścia, niż jednoznaczny wybór przekreślający wszystkie inne. Wybiera więc tożsamość lokalną:

- Jestem Polką z krwi i kości - mówiła Aba.

- Jestem Ukrainką z wyboru - powiedziała Mama.

$26 \quad$ Ibidem, s. 121.

27 Ibidem, s. 134-135. 
- Moskale, precz! - krzyknęli do mnie chłopcy. - Jestem narodowości lwowskiej - powtórzył Mikołaj za swoim mistrzem Walerym Bortiakowem. To ostatnie odpowiadało mi najbardziejej .

Bohaterka wprawdzie dostrzegała, z jaką ironią i dystansem prababka używała słowa „miejscowy”, jednak dziewczyna czuła, że właśnie to słowo najlepiej określa jej identyfikację. To bowiem nie przyporządkowanie narodowe, lecz Lwów budował i tworzył jej tożsamość. Można by stwierdzić za Jeffreyem Olickiem, że składała się ona z dwóch elementów: collected memory i collective memory ${ }^{29}$. Bohaterka zbierała zarówno doświadczenia i wiedzę jako mieszkanka Lwowa, jak też starała się odnajdować elementy lwowskiej kultury, mogące tworzyć w nim wspólnotę pamięci.

$Z$ jej perspektywy to właśnie w tym mieście znalazła swe ujście rodzinna nostalgia. Aby dokładniej prześledzić ten proces, warto odwołać się do badań literaturoznawczych, w których podejmowane są próby lokalizacji nostalgii, najczęściej poprzez poszukiwanie odniesień przestrzeni kultury do przestrzeni wewnętrznych. W Domu z witrażem jej śladów można doszukać się w pokoju babci i lwowskiej przestrzeni architektonicznej. Żanna Słoniowska w swojej powieści dotyka problemu złożoności samej tkanki miasta: jego budynków, pomników, zwyczajów.

Przewodnikiem po pejzażu semantycznym Lwowa stał się wspomniany już Mikołaj, kiedyś partner matki głównej bohaterki, z którym przeżyła fascynację - wrażliwy, zakochany w mieście wykładowca Akademii Sztuk Pięknych. To patrzenie na Lwów i jego mieszkańców z jego perspektywy pomagało jej porządkować mozaikę doświadczeń, którą odziedziczyła. Syn oddanego systemowi Rosjanina i matki z ukraińskiej rodziny zaangażowanej w walki UPA, odkrywał dla siebie to miasto z różnych perspektyw, najważniejszą z których, paradoksalnie, mogła się okazać polska.

Moim schronieniem przed ustrojem był Polski Teatr Ludowy. [...] Sztuki Różewicza i Mrożka były jak okno na inny świat. Wiesz, w polskim teatrze są nie tylko Polacy. Nasz reżyser, Walery Bortiakow, jest Rosjaninem, ale wymyślił jeszcze inne określenie, mówi o sobie, że jest narodowości lwowskiej. Ja też czuję podobnie, chociaż jestem rodowitym Ukraińcem ${ }^{30}$.

- zwierza się bohaterce. Mikołaj dzieli się z nią swoim doświadczeniem miasta i niszczących je systemów. Autorka posługuje się tą postacią, aby przywołać skądinąd znaną sytuację, kiedy aktorzy Teatru Polskiego, przedstawiciele

\footnotetext{
28 Ibidem, s. 98.

29 Pamięć zbiorowa i kulturowa. Współczesna perspektywa niemiecka, red. M. Saryusz-Wolska, Kraków 2009, s. 34.

30 Ż. Słoniowska, op. cit., s. 82.
} 
sześciu narodowości, za złożenie kwiatów pod pomnikiem Adama Mickiewicza zostali wyrzuceni z pracy i studiów za polski nacjonalizm. W powieści jednym z nich był właśnie nasz bohater. Obraz ten przedstawia charakter miejskiej wspólnoty, której członkowie pomimo wielu podziałów potrafią gromadzić się wokół wspólnych działań.

Jak zauważa Michał Urban, „bardzo ważnym elementem funkcjonowania miasta jako miejsca przebywania pewnej wspólnoty oraz jako części pewnego podmiotu politycznego, jakim jest państwo, jest nadanie mu sensu, pewnego znaczenia, które z kolei umożliwia integrację tysięcy ludzi zamieszkujących przestrzeń ograniczoną miejskimi granicami właśnie we wspólnotę"31. Żanna Słoniowska w swojej powieści dotyka rozmaitych aspektów tego funkcjonowania. Życie swoich bohaterek mocno osadziła w zmianach, którym na przestrzeni XX wieku owo miasto było poddawane.

Miasto, które w swoich wędrówkach zgłębiają córka Marianny i Mykoła, jest niemalże całkowicie pozbawione swoich rdzennych mieszkańców, zamordowanych lub wysiedlonych po II wojnie światowej. Zamieszkałe przez Rosjan - „wyzwolicieli” i przyjezdnych z okolicznych wsi w latach 60. i późniejszych, musiało stworzyć swoje nowe symbole i nową narrację. Bohaterka wraz z Mykołą poszukuje ich z pełnym zaangażowaniem. Podczas spacerów po mieście wspólnie przyglądają się kamienicom, pomnikom, tablicom pamiątkowym. Patrzą na nie uważnie, starając się dostrzec, co w sobie skrywają, a więc stare napisy, dekoracje, zniszczenia, które mówią więcej niż tylko o upływającym czasie... Jednocześnie bacznie śledzą wszelkie próby zatarcia śladów przeszłości i zastąpienia ich „nowoczesnością” w nienajlepszym tego słowa znaczeniu, gdyż „fachowa interwencja groziła wykiełkowaniem kolorowego plastiku" ${ }^{\prime 2}$ - stwierdzają.

Miejscem, które połączyło oboje bohaterów, jest tytułowy witraż na klatce schodowej zamieszkiwanej przez bohaterkę. Za inspirację posłużyło Słoniowskiej konkretne dzieło sztuki, secesyjny witraż w jednej z kamienic czynszowych przy dzisiejszej ulicy Hercena. To ogromne przedstawienie górskiego pejzażu, w który wspinał się wchodzący w górę po schodach człowiek, było, jak pisze w swoim artykule Oleksandr Owerczuk, niezwykłą próbą łączenia sztuki monumentalnej ze sztalugową. Jego dziś już nieznany autor (badacz sugeruje, że mógł zostać wykonany w „Krakowskim Zakładzie Witrażów S. G. Żeleński”) wykorzystał niezwykłą jak na sztukę witrażową liczbę siedemdziesięciu dwóch barw ${ }^{33}$.

\footnotetext{
31 M. Urban, Z drugiej strony granicy. Lwów: miasto-mit jako podstawa współczesnej tożsamości ukraińskiej, „Актуальні проблеми вітчизняної та всесвітньої історії” 2016, t. 19, irbis-nbuv.gov.ua, [dostęp: 15.12.2018].

32 Ż. Słoniowska, op. cit., s. 69.

33 O. Owerczuk, Witraż świecki we Lwowie na poczatku XX wieku: przeoczona perła, „Pamiętnik Sztuk Pięknych” 2015, nr 10, s. 227-231.
} 
W analizowanej powieści witraż staje się symbolem miasta. „Dla mnie witraż na twojej klatce schodowej jest ostatnią membraną kulturową miasta. Jeżeli pęknie, nic go nie uratuje" ${ }^{34}$ - wyznaje Mykoła swej przyjaciółce. Dla bohaterki coś, co zna od dzieciństwa, jest czymś zupełnie naturalnym i gdyby nie uwagi innych, nie dostrzegłaby jego wyjątkowości. Tak też po części dzieje się ze Lwowem, którego przestrzeń kulturową i architektoniczną większość mieszkańców traktuje jako coś zastanego. Pisarka pokazuje, że witraż jak w soczewce skupia w sobie losy miasta. Razem z nim przeżywał czasy swej świetności i razem z nim niszczeje. Zawarte w powieści opisy są swego rodzaju dokumentacją śmierci, degeneracji, procesu niszczenia. „Pamiętam dzień na początku sierpnia, kiedy w witrażu pękły pierwsze szkła. [...] Nowe luki pojawiły się trochę poniżej korzeni dębu, łącząc się z nieistniejącym od lat królestwem ognia - nicość poszerzała się jak w filmie Niekończaca się opowieść" 35 - wspomina bohaterka. Procesy te rozszerzają się i na inne przestrzenie. Realny i semantyczny pejzaż Lwowa ulega rozkładowi, zanika pamięć historii wpisana w jego przestrzeń. Bohaterka czuje się wobec tej rzeczywistości bezradna i zrezygnowana: „,- Już nie mogę o tym więcej myśleć. - stwierdza. - Myślenie jest naszym obowiązkiem. Jeśli nie my - to kto? Jeśli nie teraz - to kiedy? Jesteśmy ostatnimi Mohikanami. Tylko nam nie jest obojętne umieranie Lwowa. Nie możemy zdezerterować, nie możemy zdradzić" ${ }^{36}$ - konstatuje Mykoła. Te słowa są przesłaniem bohatera, ale też po części i autorki powieści. Życie toczy się dalej. Główna bohaterka wyprowadza się za granicę, do Lwowa przyjeżdża jedynie po to, aby odwiedzić rodzinne groby na Łyczakowie. To, co przeżyła w tym mieście, nosi jednak głęboko w sobie, poprzez te doświadczenia patrzy na wydarzenia współczesne, jak choćby kończącą powieść rewolucję godności ${ }^{37}$.

\footnotetext{
34 Ż. Słoniowska, op. cit., s. 57.

35 Ibidem, s. 173.

36 Ibidem.

37 Sposób wprowadzenia do powieści wątku rewolucji godności budzi wśród krytyków pewne zastrzeżenia. Warto tu przywołać recenzję Dariusza Nowackiego, w której autor zarzuca pisarce niekonsekwencję. „Niestety, do tej opowieści, pisanej kilka lat przed wojną na Ukrainie, został dołączony aktualny suplement. Mam na uwadze coś poważniejszego niż patetyczny finał w postaci rozdziału «Majdan». W nocie na okładce czytamy: «W trakcie pisania tej książki krew przelana za wolną Ukrainę była fikcją, w lutym 2014 roku przestała nią być». «Prawdziwa krew» modyfikuje sens tej powieści, i to radykalnie. [...] Kontrhistoria znika we mgle wybuchających granatów dymnych” - napisał D. Nowacki (Idem, ,Dom z witrażem” Żanny Stoniowskiej. Miasto kobiet [recenzja], http://wyborcza.pl/1,75410,17348869,_Dom_z_witrazem_Zanny_Sloniowskiej_Miasto_kobiet.html, [dostęp: 10.01.2019].) Nieco inaczej zapatruje się na tę kwestię ukraiński krytyk - Maksym Karpovec': „Найзворушливішим є останній розділ, присвячений Майдану. Сьогодні ця тема дещо переобтяжена ідеологічними спекуляціями, а українська література ще не готова неупереджено й відкрито відрефлексовувати ці події. Напевно, Слоньовська й не ставила собі за мету бути архіваріюсом
} 
W Domu z witrażem wszystkie bohaterki w taki czy w inny sposób przeżyły koniec świata, w którym były zakorzenione i który tworzyły, utratę tego, co miało wartość największą. Prababka nawet dwukrotnie. Żanna Słoniowska bez zbytniego patosu i uderzania w wysokie tony pochyla się nad niezwykle trudnym pytaniem o zakorzenienie - to fizyczne i duchowe. Jakie są cechy lwowskiej tożsamości, jaką funkcję spełnia ona w dyskursie ukraińskim, czym jest ojczyzna dla Polaków, którzy przeżyli dramatyczne doświadczenia bycia obywatelami Związku Radzieckiego, czym jest Lwów dla Rosjan, którzy osiedlili się tam po wojnie - o to i wiele innych trudnych spraw zdaje się pytać. Każde pokolenie znajduje inne odpowiedzi na te pytania. I kieruje się innymi przesłankami w swoich życiowych wyborach. O ile w przypadku prababki należałoby raczej mówić o ocalającej tęsknocie, wnuczka podejmuje działania doprowadzające do powrotu, zamykając jakby tym samym cykl pokoleń.

Powieść Słoniowskiej nie daje bezpośrednich odpowiedzi, czytelnik jest zaproszony do poszukiwań i zadawania dalszych pytań. Nie przedstawia opisywanej rzeczywistości ani z punktu widzenia Kresowego, ani Lwowa ukraińskiego. Poprzez losy jednostek wyciąga na światło dzienne różne wycinki rzeczywistości z bardzo różnych doświadczeń. Wielokulturowość nie jest jednak idealizowania, a postaci nie są czarno-białe. Tekst pierwotnie napisany i wydany w Polsce został przetłumaczony na język ukraiński, wchodząc w tym samym w dyskursy obu literatur i zapraszając do wzajemnej wrażliwości na swoje kultury.

\section{BIBLIOGRAFIA}

Bakuła Bogusław. 2016. Pamięć: ciagłość i zerwanie. Ojcowie i dzieci wobec historii we współczesnej powieści i filmie z Europy środkowo-wschodniej (na wybranych przykładach). W: Posttotalitarny syndrom pokoleniowy w literaturach stowiańskich Europy Środkowej, Wschodniej i Poludniowo-Wschodniej końca XX-początku XXI wieku $w$ świetle studiów postkolonialnych. Red. nauk. A. Matusiak. Poznań - Wrocław: Bonami: 195-224.

(хоча може скластися таке враження), адже їй важливо передати емоцію [...]. Водночас у цьому - у чуттєвості героїнь, яка обертається в надмірну естетизацію дійсности, й найбільша слабкість книжки.” (М. Карповець, Жанна Слоньовська. Дім з вітражем, https://krytyka.com/ua/reviews/dim-z-vitrazhem, [dostęp: 1.10.2019]. Natomiast sama pisarka tak uzasadnia wybór zakończenia powieści: „Wydarzenia na Majdanie miały miejsce, kiedy jeszcze nie wiedziałam, jak będzie wyglądało zakończenie mojej książki. W pierwszym rozdziale opisuję fikcyjną walkę Ukraińców o wolność. Kiedy zobaczyłam prawdziwe zwłoki owinięte w żołto-niebieskie flagi, zrozumiałam, że fikcja miesza się z prawdą, a historia przenika do fabuły powieści" (Żanna Słoniowska: wzrusza mnie polsko-ukraińska solidarność, https:// kultura.onet.pl/wiadomosci/zanna-sloniowska-wzrusza-mnie-polsko-ukrainska-solidarnosc/ xh4bnl0, [dostęp: 10.01.2019]. 
Czapik-Lityńska Barbara. 2013. Topografia nostalgii jako topografia tożsamości (na podstawie twórczości Dubravki Ugrešić i Pavao Pavličicia). „Porównania” t. XII: 103-116.

Czapliński Przemysław. 2001. Wzniosłe tęsknoty. Nostalgie w prozie lat dziewięćdziesiatych. Warszawa: Wydawnictwo Literackie.

Delsol Chantal. 2003. Esej o człowieku późnej nowoczesności. Kraków: Społeczny Instytut Wydawniczy Znak.

Joas Hans. 2009. Powstawanie wartości. Tłum. M. Kaczmarczyk. Warszawa: Oficyna Naukowa.

Karpovec' Maksim. 2017 Žanna Slon'ovs'ka. Dìm z vìtražem. https://krytyka.com/ua/reviews/dim-z-vitrazhem [dostęp: 1.10.2019].

Kotyńska Katarzyna. 2015. Lwów. O odczytywaniu miasta na nowo. Kraków: Międzynarodowe Centrum Kultury.

Matusiak Agnieszka, Świetlicki Mateusz. 2016. Kategoria pokolenia we współczesnych badaniach spoleczno-kulturowych. W: Posttotalitarny syndrom pokoleniowy w literaturach słowiańskich Europy Środkowej, Wschodniej i Poludniowo-Wschodniej końca XX-poczatku XXI wieku w świetle studiów postkolonialnych. Red. nauk. A. Matusiak. Poznań-Wrocław: Bonami: 15-34.

Nikitorowicz Jerzy. 2015. Model ksztaltowania się tożsamości kulturowej w warunkach wielokulturowości. „Psychologia Wychowawcza” nr 7: 125-134.

Nowacki Dariusz. 2015. „, Dom z witrażem” Zanny Słoniowskiej. Miasto kobiet [recenzja]. http://wyborcza.pl/1,75410,17348869,_Dom_z_witrazem_ZZanny_Sloniowskiej_ Miasto_kobiet.html, [dostęp: 10.01.2019].

Owerczuk Öłeksandr. 2015. Witraż świecki we Lwowie na początku XX wieku: przeoczona perta. „Pamiętnik Sztuk Pięknych” nr 10: 227-231.

Pamięć zbiorowa i kulturowa. Współczesna perspektywa niemiecka. 2009. Red. M. Saryusz-Wolska. Kraków: Universitas.

Słoniowska Żanna. 2015. Dom z witrażem. Kraków: Społeczny Instytut Wydawniczy Znak.

Szulc Anna. 2015. Przypadki chodza po Lwowie, czyli „Dom z witrażem” Stoniowskiej [recenzja], https://www.newsweek.pl/kultura/dom-z-witrazem-zanny-sloniowskiej-recenzja-ksiazki-o-lwowie/tcmdh5j, [dostęp: 4.07.2019].

Urban Michał. 2016. Z drugiej strony granicy. Lwów: miasto-mit jako podstawa wspótczesnej tożsamości ukraińskiej. „Aktual'ni problemy vitchyznyanoyi ta vsesvitn'oy iistoriyi” [„Актуальні проблеми вітчизняної та всесвітньої історіï”] t. 19. W: irbis-nbuv.gov.ua. [dostęp: 15.12.2018].

Wolska Danuta. 2012. Odzyskać doświadczenie. Sporny temat humanistyki współczesnej. Kraków: Universitas.

Žanna Slon'ovs'ka: «Opisala L'vìv âk vlasne tìlo, devulicì-kapilâri» [Жанна Слоньовська: «Описала Львів як власне тіло, де вуличі - капіляри»]. 2015. https://starylev.com. ua/news/zhanna-slonovska-opysala-lviv-yak-vlasne-tilo-de-vulyci-kapilyary, [dostep: 10.01.2019].

Żanna Słoniowska: wzrusza mnie polsko-ukraińska solidarność. 2015. https://kultura. onet.pl/wiadomosci/zanna-sloniowska-wzrusza-mnie-polsko-ukrainska-solidarnosc/ xh4bnl0, [dostęp: 10.01.2019]. 


\title{
LVIV IN THE $20^{\mathrm{TH}}-21^{\mathrm{ST}}$ CENTURY. THE PROCESS OF GROWING UP AND THE GENERATIONAL CONFLICT IN THE TIME OF SOCIAL CHANGE AND REVOLUTIONS (BASED ON THE HOUSE WITH A STAINED-GLASS WINDOW BY ŻANNA SŁONIOWSKA)
}

Summary. In the article, the novel House with a stained glass by Żanna Słoniowska was analysed in terms of relations between the four generations of women living in it. The focus was on the process of shaping the identity of the youngest heroine. The impact of the experience of terror and war on her grandmother and grandmother, as well as the political involvement and death of her mother were analysed. I also looked for an answer to the question about the place that Lviv and its semantic landscape occupy in the process of shaping her identity.

Keywords: Żanna Słoniowska, House with a stained glass, Lviv, identity, historical experience, generation gap.

\section{ЛЬВІВ ХХ-ХХІ СТОЛІТТЯ. ВИРОСТАННЯ ТА КОНФЛІКТ ПОКОЛІНЬ В ЕПОХУ СОЦІАЛЬНИХ ЗМІН ТА РЕВОЛЮЦІЇ (НА ОСНОВІ ДОМУ 3 ВІТРАЖЕМ ЖАННИ СЛОНЬОВСЬКОї)}

\begin{abstract}
Анотація. Метою даної статті є аналіз роману Жанни Слоньовської Дім з вітражем 3 точки зору стосунків між чотирма поколіннями жінок, які там проживали. Основна увага дослідниці приділялася процесові формування особистості наймолодшої героїні. Авторка статті проаналізувала вплив, який на згадану героїню мали переживання терору та війни прабабусею та бабусею, а також політична заангажованість та смерть матері. У процесі літературних досліджень було також зроблено спробу знайти відповідь на питання про місце, яке Львів та його смисловий пейзаж займають у процесі формування ідентичності головної героїні.
\end{abstract}

Ключові слова: Жанна Слоньовська, Дім з вітражем, Львів, ідентичність, історичний досвід, конфлікт поколінь. 